\title{
Diagnosis of genital human papillomavirus (HPV) lesions in the male: Correlation of peniscopy, histology and in situ hybridisation
}

\author{
M I Hippeläinen, S Syrjänen, M J Hippeläinen, S Saarikoski, K Syriänen
}

\begin{abstract}
Objective-To assess the diagnostic criteria of genital HPV lesions in male sexual partners of HPV infected women.

Methods-Peniscopically directed biopsy specimens (from 693 lesions in 300 men) were examined on light microscopy and in situ hybridisation (ISH) for HPV types $6,11,16,18,31,33$ and 42 . The predictive value of different histological criteria for ISH positivity was also evaluated using stepwise logistic regression analysis.

Results-Flat HPV lesions were most accurately predicted by the punctuation pattern on peniscopy, giving the concordance between peniscopy and histology of $79.5 \%(66 / 83)$ and that between peniscopy and ISH of $56 \cdot 6 \%(47 / 83)$. Diffuse acetowhite pattern disclosed a typical HPV lesion in only $17 \cdot 8 \%(13 / 73)$, and HPV DNA was found in $11.0 \%(8 / 73)$ of cases. Of the 114 biopsy specimens from peniscopically healthy areas adjacent $(0 \cdot 5-1 \mathrm{~cm})$ to the lesions, $93 \cdot 0 \%(106 / 114)$ were normal on light microscopy, and HPV DNA was found in only $2 \cdot 6 \%$. Penile intraepithelial neoplasia (PIN) lesions were most frequently ISH positive, $81 \cdot 1 \%$ (30/37), 50\% showing HPV 16 and/or 18 DNA. Lesions classified as HPV-suspicious or nonspecific on light microscopy were HPV DNA-positive in $16.9 \%(11 / 65)$ and $8 \cdot 1 \%(13 / 160)$, the frequency of high-risk HPV types being $3.1 \%$ and $1.3 \%$, respectively. In logistic regression analysis, koilocytosis was the most powerful predictor of ISH-positivity in the flat lesions (without PIN), the risk ratio being $3 \cdot 7$.
\end{abstract}

Conclusion-No conclusive peniscopic criteria for male HPV infections could be established, making histological evaluation mandatory. Care should be exercised in interpreting as HPV lesions the cases devoid of koilocytosis, HPV typing being essential in confirming the diagnosis in doubtful cases.

(Genitourin Med 1993;69:346-351)

\section{Introduction}

There is substantial evidence linking HPV to female genital squamous cell cancer. ${ }^{123}$ As a sexually transmitted disease, increasing interest has been focused on male HPV infections as well, the majority of which seem to appear subclinical and remain invisible to the naked eye. ${ }^{4-8}$
During the past few years, the role of acetic acid application and peniscopy has been emphasised in the diagnosis of male HPV lesions. ${ }^{457-12}$ No uniformly accepted peniscopic criteria have been elaborated for the HPV-associated acetowhite lesions in the literature. ${ }^{8}$ It is obvious, however, that acetowhite changes comprise a spectrum of histological abnormalities, ${ }^{9-11}$ and only a part of the peniscopically HPV-suspect or even typical flat HPV lesions can be histologically confirmed as HPV infections. ${ }^{10-13}$

Recent advances in HPV detection techniques by hybridisation or PCR have added to the diagnostic difficulty. ${ }^{14} \mathrm{HPV}$ DNA can be disclosed in biopsies which do not meet the histological criteria of classical HPV lesions. ${ }^{12}{ }^{15-18}$ Conversely, lesions classified as condylomata on light microscopy can be negative by hybridisation tests. ${ }^{12} 151819$ Such findings can be attributed to the insensitivity of the hybridisation techniques or inappropriate DNA probes used. ${ }^{13}$ 20-22 On the other hand, HPV infections have a wide biological spectrum from a clinical disease to latent infections. In the latter, HPV should be confined to entirely normal epithelium, being detectable only by hybridisation or PCR. ${ }^{141821}$

Histological diagnosis of condyloma is based on the presence of koilocytosis, ${ }^{23-25}$ albeit papular lesions (pigmented papulosis, Bowenoid papulosis) commonly do not show these cytopathic changes of HPV. ${ }^{3818}$ Increased awareness of clinicians for HPV infections has resulted in an increased number of biopsies from the male genitals as well. The findings are not always easy to interpret, however, while containing subtle changes resembling those found in condylomas (i.e., acanthosis, hyper-keratosis, parakeratosis), but showing no conclusive evidence of HPV infection even if DNA detection methods are used. $^{818}$ To cope with this uncertainty, pathologists have started using ambiguous terms such as "suggestive of condyloma, borderline condyloma, subclinical HPV infection". 1011212526 Such diagnostic terms with associated peniscopic abnormalities may be confusing for clinicians, leading to unnecessary ablative therapy in patients who actually never had an HPV-infection.

In the present study, an attempt was made to search for uniform diagnostic criteria of the male genital HPV infections, by comparing the peniscopic and histological findings with each other and as related to HPV DNA detection by in situ hybridisation (ISH) assay. 


\section{Material and methods}

The material of the present study consists of 300 male sexual partners of women with histologically proven HPV infection, examined on the basis of abnormal Papanicolaou (PAP) smears. All males attended the Outpatient Department of Gynaecology and Obsterics, Kuopio University Hospital, voluntarily, and were subjected to peniscopic evaluation (after acetic acid) of the entire genital tract, as previously detailed. ${ }^{10}$ From each patient, one or two biopsy samples were taken from peniscopically abnormal areas (altogether 579). In addition, 114 samples were taken from peniscopically healthy mucosa, adjacent to $(0.5-1$ $\mathrm{cm}$ ) the biopsied lesion. Each biopsy specimen was fixed in $10 \%$ formalin and processed for routine histology and ISH according to routine procedures.

\section{Peniscopic examination}

All patients were examined by one of us (MIH) using an Olympus photocolposcope (peniscopy) at magnification 6-16x. Lesions were described according to their appearance as either (a) condyloma acuminatum (b) papular or (c) acetowhite flat lesions with or without sharp demarcation, elevated or having a punctuated capillary pattern. Papules were defined as well circumscribed elevated lesions with a smooth surface, and clearly distinct from condyloma acuminatum. Leukoplakia (white epithelium before acetic acid) and ulcers were also noted.

\section{Histological examination}

Altogether, 693 biopsy specimens were evaluated on light microscopy by a single pathologist (KS). The histological findings were classified into one of the following categories: 1) condyloma acuminatum, 2) flat condyloma, 3) papulosis 4) suspicious for HPV, 5) nonspecific, and 6) healthy mucosa. The criteria used in categorising the HPV lesions according to their light microscopic appearance have been published previously. ${ }^{3818}$ Lesions with subtle changes, such as mild acanthosis or parakeratosis, no typical koilocytes, and minimal or no cellular atypia, were classified as suspicious for HPV (equivalent to subclinical HPV infection?). Findings devoid of any morphological evidence for HPV were classified as nonspecific, that is, usually inflammation, hyper- or parakeratosis.

Table 1 Histological findings behind the peniscopic patterns

\begin{tabular}{|c|c|c|c|c|c|}
\hline \multirow[b]{2}{*}{$\begin{array}{l}\text { Peniscopic } \\
\text { Appearance }\end{array}$} & \multirow[b]{2}{*}{ No. } & \multicolumn{4}{|l|}{ Histology } \\
\hline & & $\begin{array}{l}\text { Typical HPV } \\
\text { No. (\%) }\end{array}$ & $\begin{array}{l}\text { Susp. HPV } \\
\text { No. (\%) }\end{array}$ & $\begin{array}{l}\text { Nonsp. } \\
\text { No. (\%) }\end{array}$ & $\begin{array}{l}\text { Healthy } \\
\text { No. (\%) }\end{array}$ \\
\hline $\begin{array}{l}\text { Acuminatum } \\
\text { Papular } \\
\text { Acetowhite } \\
\text {-diffuse } \\
\text { - well demarc. } \\
\text { - + elevated } \\
\text { - + punctuation } \\
\text { Leukoplakia } \\
\text { Ulceration } \\
\text { Herpes } \\
\text { Healthy } \\
\text { Total }\end{array}$ & $\begin{array}{r}57 \\
87 \\
419 \\
73 \\
81 \\
182 \\
83 \\
2 \\
12 \\
2 \\
2 \\
114 \\
693\end{array}$ & $\begin{aligned} 53(93.0) \\
52(59.8) \\
222(53.0) \\
13(17.8) \\
36(44 \cdot 4) \\
107(58 \cdot 8) \\
66(79 \cdot 5) \\
1(50.0) \\
4(33 \cdot 3) \\
0 \\
1(0.9) \\
333(48 \cdot 1)\end{aligned}$ & $\begin{array}{c}0 \\
6(6 \cdot 9) \\
56(13 \cdot 4) \\
7(9 \cdot 6) \\
14(17 \cdot 3) \\
25(13 \cdot 7) \\
10(12 \cdot 0) \\
0 \\
0 \\
0 \\
3(2 \cdot 6) \\
65(9 \cdot 4)\end{array}$ & $\begin{array}{c}3(5 \cdot 3) \\
23(26 \cdot 4) \\
120(28 \cdot 6) \\
46(63 \cdot 0) \\
27(33 \cdot 3) \\
40(22 \cdot 0) \\
7(8 \cdot 4) \\
1(50 \cdot 0) \\
7(58 \cdot 3) \\
2(100) \\
4(3 \cdot 5) \\
160(23 \cdot 1)\end{array}$ & $\begin{array}{c}1(1 \cdot 8) \\
6(6.9) \\
21(5 \cdot 0) \\
7(9 \cdot 6) \\
4(4 \cdot 9) \\
10(5 \cdot 5) \\
0 \\
0 \\
1(8 \cdot 3) \\
0 \\
106(93 \cdot 0) \\
135(19 \cdot 5)\end{array}$ \\
\hline
\end{tabular}

For the present analysis, all biopsy samples were scored according to 10 different histological characteristics previously associated with HPV infections; koilocytosis, cell vacuolisation, papillomatosis, acanthosis, hyperkeratosis, parakeratosis, dyskeratosis, inflammation, hypergranulosis and dysplasia. Penile intraepithelial neoplasia (PIN), characterised by disorganised epithelial layers and cellular polarity, nuclear atypia, and abnormal mitotic figures, was graded according to the principles followed for intraepithelial neoplasia in the female genital tract as defined previously. ${ }^{3818}$

\section{In situ hybridisation (ISH)}

All biopsies were analysed for the presence of HPV DNA using the ISH applied on paraffin sections. The ISH technique routinely used in our laboratory is based on biotin-labelled DNA probes for HPV types $6,11,16,18,31$, 33 and 42 , as previously detailed. ${ }^{20278}$

\section{Statistical methods}

To analyse the correlations between different histological criteria and ISH, Pearson's correlation coefficient was used. Distribution of class variables were tested with the chi square test or with Fischer's exact test when adequate. The value of the different histological characteristics to predict HPV DNA-positivity in the flat lesions (both typical HPV, suspicious HPV, and nonspecific ones) was assessed with logistic regression analysis used in a stepwise manner; variable selection was based on likelihood ratio statistics. Analysis was carried out with the following variables as predictors: koilocytosis, papillomatosis, acanthosis, vacuolisation, parakeratosis, hyperkeratosis, dyskeratosis, hypergranulosis and inflammatory changes. All calculations were carried out with the SPSSPC v4.01 computer programme.

\section{Results}

Histological findings behind the different peniscopic patterns are summarised in table 1. Condyloma acuminatum was highly accurately diagnosed on peniscopy $(93 \%)$, and a similar accuracy (93\%) was obtained when the biopsies from peniscopically healthy areas were assessed on light microscopy. Diffuse acetowhite lesions were poor predictors of HPV infection, a typical lesion being confirmed in only $17 \cdot 8 \%(13 / 73)$ of cases. However, sharp demarcation, elevation and punctuation pattern of the acetowhite lesions increased the HPV-predictability of peniscopy to $79 \cdot 5 \%(66 / 83)$. Whereas $25 \cdot 3 \%$ of the flat lesions with punctuation pattern disclosed a PIN, only $1.4 \%$ of the diffuse acetowhite lesions were due to PIN. Of the papular lesions, most of the smallest ones $(<5 \mathrm{~mm}$, often on the shaft), appeared to be either nonspecific or flat condylomas. Instead, all the pigmented papules were typical HPV lesions, seven of them being Bowenoid papulosis. Two lesions were classified as leukoplakia; just another of them showed typical 
Table 2 HPV DNA in lesions with different peniscopic patterns

\begin{tabular}{lrcr}
\hline Peniscopy & No. & $\begin{array}{l}\text { ISH-positive } \\
\text { No. }(\%)\end{array}$ & \multicolumn{1}{c}{$\begin{array}{l}\text { ISH-negative } \\
\text { No. (\%) }\end{array}$} \\
\hline Acuminatum & 57 & $48(84 \cdot 2)$ & $9(15 \cdot 8)$ \\
Papular & 87 & $32(36 \cdot 8)$ & $55(63 \cdot 2)$ \\
Acetowhite & 419 & $100(23 \cdot 9)$ & $319(76 \cdot 1)$ \\
$\quad$-diffuse & 73 & $8(11 \cdot 0)$ & $65(89 \cdot 0)$ \\
-well demarc. & 81 & $9(11 \cdot 1)$ & $72(88 \cdot 9)$ \\
- + elevated & 182 & $36(19 \cdot 8)$ & $146(80 \cdot 2)$ \\
- + punctuation & 83 & $47(56 \cdot 6)$ & $36(43 \cdot 4)$ \\
Leukoplakia & 2 & 0 & $2(100)$ \\
Ulceration & 12 & $1(8 \cdot 3)$ & $11(91 \cdot 7)$ \\
Herpes & 2 & 0 & $2(100)$ \\
Healthy & 114 & $3(2 \cdot 6)$ & $111(97 \cdot 4)$ \\
Total & 693 & $184(26 \cdot 6)$ & $509(73 \cdot 4)$ \\
\hline
\end{tabular}

features for HPV on light microscopy.

The detection of HPV DNA by ISH as related to peniscopic patterns is shown in table 2. Condylomata acuminata were almost invariably HPV DNA-positive (84.2\%), whereas peniscopically normal epithelium showed HPV DNA in only $2 \cdot 6 \%$ of cases (3/114). Diffuse acetowhite flat lesions were mostly ISH-negative $89.0 \%(65 / 73)$, whereas $56.6 \%$ of the well demarcated, elevated lesions with punctuation pattern were ISHpositive $(47 / 83)$. The distribution of different flat lesions between ISH positive and negative groups was statistically significant $(p<$ 0.001 ).

HPV types in different penile lesions are depicted in table 3 . The concordance between histology and HPV typing was equally high in condylomata acuminata and PIN, $81 \cdot 1 \%$, but the distribution of high and low risk types was significantly different $(p<$ $0 \cdot 001$ ). The high risk types 16 and 18 were confined to PIN and typical flat lesions in

Table 3 HPV DNA in different penile lesions

\begin{tabular}{lccccc}
\hline \multirow{5}{*}{ Histology } & \multicolumn{5}{c}{ ISH-positive, No.(\%) } \\
\cline { 2 - 6 } \cline { 3 - 5 } & No (\%) & \multicolumn{1}{c}{$6 / 11$} & \multicolumn{1}{c}{$16 / 18$} & $31,33,42$ \\
\hline PIN $^{\star}$ & 37 & $30(81 \cdot 1)$ & $4(10 \cdot 8)$ & $15(40 \cdot 5)$ & $11(29 \cdot 7)$ \\
Acuminatum & 53 & $43(81 \cdot 1)$ & $41(77 \cdot 4)$ & 0 & $2(3 \cdot 8)$ \\
Papular & 45 & $22(48 \cdot 9)$ & $15(33 \cdot 3)$ & $3(6 \cdot 7)$ & $4(8 \cdot 9)$ \\
Flat & 198 & $60(30 \cdot 3)$ & $32(16 \cdot 2)$ & $13(6 \cdot 6)$ & $15(7 \cdot 6)$ \\
Susp flat & 65 & $11(16 \cdot 9)$ & $5(7 \cdot 7)$ & $2(3 \cdot 1)$ & $4(6 \cdot 2)$ \\
Nonspef & 160 & $13(8 \cdot 1)$ & $8(5 \cdot 0)$ & $2(1 \cdot 3)$ & $3(1 \cdot 9)$ \\
Healthy & 135 & $9(6 \cdot 7)$ & $6(4 \cdot 4)$ & 0 & $3(2 \cdot 2)$ \\
Total & 693 & $188(27 \cdot 2)$ & $111(16 \cdot 0)$ & $35(5 \cdot 1)$ & $42(6 \cdot 1)$ \\
\hline
\end{tabular}

$\star 7$ Bowenoid papulosis, 30 flat lesions

Table 4 Morphological characteristics related to detection of HPV DNA by ISH

\begin{tabular}{|c|c|c|c|}
\hline $\begin{array}{l}\text { Morphological } \\
\text { Feature }\end{array}$ & $\begin{array}{l}\text { Positive } \\
\text { Biopsies } \\
N=188\end{array}$ & $\begin{array}{l}\text { ISH- } \\
\text { Negative } \\
\text { Biopsies } \\
N=505\end{array}$ & $I S H-$ \\
\hline $\begin{array}{l}\text { Non-PIN-lesions } \\
\text { - papillomatosis } \\
\text { - koilocytosis } \\
\text { - vacualisation } \\
\text { - acanthosis } \\
\text { - parakeratosis } \\
\text { - hyperkeratosis } \\
\text { - dyskeratosis } \\
\text { - inflammation } \\
\text { - hypergranulosis } \\
\text { PIN } \\
\text { healthy }\end{array}$ & $\begin{array}{l}\text { No. }(\%) \\
21(11 \cdot 2) \\
127(67 \cdot 6) \\
13(6 \cdot 9) \\
116(61 \cdot 7) \\
68(36 \cdot 2) \\
50(26 \cdot 6) \\
3(1 \cdot 6) \\
22(11 \cdot 7) \\
16(8 \cdot 5) \\
30(16 \cdot 0) \\
9(4 \cdot 8)\end{array}$ & $\begin{array}{c}\text { No. }(\%) \\
4(0 \cdot 8) \\
135(26 \cdot 7) \\
74(14 \cdot 7) \\
204(40 \cdot 4) \\
110(21 \cdot 8) \\
160(31 \cdot 7) \\
4(0 \cdot 8) \\
80(15 \cdot 8) \\
14(2 \cdot 8) \\
7(1 \cdot 4) \\
126(25 \cdot 0)\end{array}$ & $\begin{array}{l}\mathrm{p}<0.001 \\
\mathrm{p}<0.001 \\
\mathrm{p}=0.001 \\
\mathrm{p}<0.001 \\
\mathrm{p}<0.001 \\
\mathrm{p}=0.21 \\
\mathrm{p}<0.001 \\
\mathrm{p}=0.18 \\
\mathrm{p}=0.003 \\
\mathrm{p}<0.001 \\
\mathrm{p}<0.001\end{array}$ \\
\hline
\end{tabular}

PIN ${ }^{\star}: 7$ Bowenoid papulosis and 30 flat lesions
$80 \%(28 / 35)$ and never found in condyloma acuminata. On the other hand, HPV types 6 and 11 were found in $77.4 \%(41 / 53)$ of condylomata acuminata and in $33.3 \%$ (15/45) of papulosis lesions. Most interestingly, HPV 6 and/or 11 were detected also in $10.8 \%$ of PIN lesions (4/37). HPV detection rate was substantial $(16.9 \%)$ in histologically HPV-suspicious lesions, but markedly lower $(8.1 \%)$ in those classified as nonspecific. Histologically normal epithelium adjacent to the lesions showed HPV DNA in $6.7 \%$ $(9 / 135)$ of cases.

The distribution of different histological criteria in ISH-positive and ISH-negative biopsies is shown in table 4. Only hyperkeratosis and inflammatory changes were practically identical in these two groups, all the other histological characteristics being significantly $(p<0.001)$ different in HPV-positive and HPV-negative lesions. When analysed using Pearson's correlation coefficient, the histological features correlating significantly with the HPV-positivity were koilocytosis ( $r=$ $0.37, \mathrm{p}<0.001)$, papillomatosis $(\mathrm{r}=0.25, \mathrm{p}$ $<0.001)$, acanthosis $(r=0.18, p<0.001)$, parakeratosis $(\mathrm{r}=0.15, \mathrm{p}<0.001)$, and hypergranulosis $(r=0.12, \mathrm{p}<0.01$ ) (data not shown in tables). In stepwise logistic regression analysis, koilocytosis, papillomatosis and hypergranulosis were selected as independent predictors for HPV-positivity. Koilocytosis was the single most powerful predictor, the risk ratio (RR) being $3 \cdot 7$.

The influence of lesion size and location on HPV-detectability on histology and ISH is summarized in table 5 (altogether 579 lesions). The largest sharply demarcated lesions were most frequently typical HPV lesions on light microscopy, and HPV DNApositive on ISH as well. Confluent lesions consisted of huge exophytic condylomas sometimes with adjacent flat lesions, or were clinically consistent with balanoposthitis and prominent infection. Histologically typical HPV lesions had distinct sites of predilection in the male genitalia; urethral and meatal lesions were most frequently typical HPV, $100 \%(15 / 15)$ and $70 \%(7 / 10)$, respectively, whereas lesions on the glans and in the

Table 5 Lesion size and location as related to histology and HPV DNA detection

\begin{tabular}{lcrr}
\hline $\begin{array}{l}\text { (a) Size of } \\
\text { lesion }\end{array}$ & $\begin{array}{c}\text { Total series } \\
N(\%)\end{array}$ & $\begin{array}{l}\text { Histologically } \\
\text { typical lesions } \\
N(\%)\end{array}$ & $\begin{array}{l}\text { ISH-positive } \\
\text { lesions } \\
N(\%)\end{array}$ \\
\hline 1-2mm & $207(35 \cdot 8)$ & $105(50 \cdot 7)$ & $42(20 \cdot 3)$ \\
$2-10 \mathrm{~mm}$ & $259(44 \cdot 7)$ & $165(63 \cdot 7)$ & $86(33 \cdot 2)$ \\
$>10 \mathrm{~mm}$ & $58(10 \cdot 1)$ & $46(79 \cdot 3)$ & $29(50 \cdot 0)$ \\
Confluent & $54(9 \cdot 3)$ & $25(46 \cdot 3)$ & $17(31 \cdot 5)$ \\
(b) Site of lesion & & & \\
\hline Urethra & $15(2 \cdot 6)$ & $15(100)$ & $12(80 \cdot 0)$ \\
Meatus & $10(1 \cdot 7)$ & $7(70 \cdot 0)$ & $4(40 \cdot 0)$ \\
Glans & $13(2 \cdot 2)$ & $3(23 \cdot 1)$ & $2(15 \cdot 4)$ \\
Sulcus & $60(10 \cdot 4)$ & $25(41 \cdot 7)$ & $16(26 \cdot 7)$ \\
Prepuce & $225(38 \cdot 9)$ & $137(60 \cdot 9)$ & $75(33 \cdot 3)$ \\
Frenulum & $67(11 \cdot 6)$ & $24(35 \cdot 8)$ & $9(13 \cdot 4)$ \\
Shaft & $148(25 \cdot 6)$ & $95(64 \cdot 2)$ & $45(30 \cdot 4)$ \\
Scrotum & $14(2 \cdot 4)$ & $6(42 \cdot 9)$ & $3(21 \cdot 4)$ \\
Anus & $10(1 \cdot 7)$ & $7(70 \cdot 0)$ & $2(20 \cdot 0)$ \\
Groins & $10(1 \cdot 7)$ & $6(60 \cdot 0)$ & $7(70 \cdot 0)$ \\
Pubic & $6(1 \cdot 0)$ & $5(83 \cdot 3)$ & $2(33 \cdot 3)$ \\
\hline
\end{tabular}


Table 6 HPV-types related to peniscopic and morphologic evidence for HPV

\begin{tabular}{llll}
\hline & No. of & $\begin{array}{l}\text { Peniscopically } \\
\text { Typical HPV } \\
\text { No. (\%) }\end{array}$ & $\begin{array}{l}\text { Histologically } \\
\text { Typical HPV } \\
\text { No. (\%) }\end{array}$ \\
\hline $6 / 11$ & 111 & $92(82 \cdot 9)$ & $92(82 \cdot 9)$ \\
$16 / 18$ & 35 & $28(80 \cdot 0)$ & $31(88 \cdot 6)$ \\
$31,33,42$ & 42 & $33(78 \cdot 6)$ & $25(59 \cdot 5)$ \\
ISH- & 505 & $163(32 \cdot 3)$ & $180(35 \cdot 6)$ \\
\hline
\end{tabular}

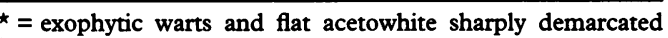
lesions

frenulum were more often nonspecific and not consistent with HPV infection, 75.0\% and $64.2 \%$, respectively. This distribution of HPV lesions closely correlated with the detectability of HPV DNA by ISH, being highest in the lesions of urethra and meatus, and lowest in those of the glans and frenulum (table 5).

Of the ISH-positive lesions with high risk types 16 and 18, 20\% were not typical for HPV peniscopically (were diffuse acetowhite lesions). On the other hand, the high-risk types were never found from the epithelium classified as normal on peniscopy. Similarly, $11.4 \%$ of the biopsies containing high-risk types were not histologically typical for HPV. Some $30 \%$ of ISH-negative lesions were peniscopically and histologically typical for HPV, as shown in table 6 .

\section{Discussion}

In the proper diagnosis of male genital lesions, it is essential to assess what proportion of the visible lesions in men known to be exposed to the virus (that is, sexual partners of HPV-infected women) are HPV-related. In the present study, peniscopical and histological criteria used in the diagnosis of genital HPV infections were evaluated using the HPV DNA detection by ISH as a reference.

The role of peniscopy in HPV diagnosis has been discussed in an increasing number of recent reports, ${ }^{4-12} 29$ but reliable diagnostic criteria have not been elaborated as yet. Many studies have emphasised, however, that the most consistent single pattern of penile flat HPV lesions is the presence of a well demarcated, slightly elevated acetowhite epithelium in which a capillary punctuation can be distinguished. ${ }^{5912}$ This is consistent with our experience as well. When examined on light microscopy, none of the lesions with the above pattern were normal, but instead, $91.6 \%$ of them were morphologically typical or suspicious HPV (table 1), and $56.6 \%$ showed HPV DNA (table 2). If, however, the punctuation pattern of capillary had been the demanded criteria for obvious flat HPV lesions evaluated by peniscopy, only $22.7 \%$ $(66 / 222)$ of the lesions classified as typical for HPV on light microscopy, had been detected. But by counting all the sharply demarcated lesions (elevated or not) with punctuation, $\mathbf{9 4 . 1 \%}$ of histologically typical HPV lesions were found.

In some recent reports, ${ }^{21} 29$ the question has been raised on the usefulness of peniscopy, while especially the smallest lesions seem to be often histologically nonspecific and HPV DNA is not found. In our study, the lesions ranging from 1-2mm, were histologically typical flat lesions in $50.7 \%$ of cases and ISHpositivity was found in $20.3 \%$. Thus, these small flat lesions should not be neglected if correct diagnosis is to be reached. However, in the future it would be more rewarding to classify the papules according to their size; the smallest ones $(<5 \mathrm{~mm})$ usually being nonspecific or suspicious flat lesions on light microscopy. On the other hand, pigmented papules almost invariably showed histological features of PIN as has been reported by others. ${ }^{49}$ The site of the lesion can only suggest the possible diagnosis.

Although we were not able to establish conclusive peniscopic criteria for flat HPV lesions, we do stress the importance of peniscopy, because even small exophytic warts may be overlooked without adequate magnification and a good light source. The reliability of peniscopy in evaluating the extent of HPV infection and disclosing the disease is well established by our results; $93.0 \%$ of the peniscopically healthy areas adjacent to the lesion were histologically normal (table 1). Only $2 \cdot 6 \%$ of them were ISH-positive, but never contained HPV types 16 and 18 . However, the use of acetic acid without peniscopy must be cautioned, because of a great number of false positive results, as reported before. ${ }^{15212926}$ Another question is whether acetic acid application is of clinical use in searching for subclinical (mostly symptomless) lesions in the male genitalia.

The present results clearly indicate that no major problems are encountered in making the correct diagnosis of classical warts and intraepithelial neoplasia lesions. There was a good correlation between histology and ISH in condyloma acuminatum and PIN lesions, both being ISH-positive in close to $80 \%$ of cases. The distribution of different HPV types was consistent with the previous reports, ${ }^{4} 9121530$ the high-risk types being most frequent in PIN lesions. The correlation of histology and ISH in the flat N-PIN lesions was more poor, however, since only $30 \%$ of even typical flat lesions showed HPV DNA. This is in agreement with the earlier findings of Nuovo et al, who reported that lesions clinically resembling condylomata frequently did not contain detectable HPV DNA when koilocytotic atypia and multinucleation were absent. ${ }^{21}$ Similar problems are encountered while evaluating the flat vulvar lesions as well. ${ }^{21}$ Noteworthy was the observation that histologically nonspecific lesions were ISHpositive in $8.1 \%$ of cases, showing the highrisk HPV types in $1.3 \%$. This emphasises the difficulty in making the morphological diagnosis of subclinical HPV infections, as recently pointed out. ${ }^{18}$

An attempt was also made to evaluate the predictive value of histologic criteria used in diagnosis of HPV-associated NPIN-lesions (as confirmed by ISH). There was a statisti- 
cally significant difference in the prevalence of most of these histological criteria between the ISH-positive and ISH-negative lesions (table 4). However, the model constructed on the basis of our stepwise logistic regression analysis to predict the ISH-positivity in flat lesions, is hardly useful; although it could predict $80 \%$ of the specimens correctly, only $8 \%$ of the ISH-positive findings were correct positive ones.

In the present material, the biopsy samples subjected to light microscopic analysis were identical to those analysed for HPV DNA, thus providing a direct comparison of the histological features with the HPV detection. Seven of the most common genital HPV types were analysed by ISH. Using different hybridisation methods together or with PCR, the HPV-detection rate might have been higher. ${ }^{12} 131617$ It seems likely, however, that no clinically important lesions remained undetected, as suggested by the analysis of PIN and condyloma acuminatum lesions which were invariably ISH-positive. Interestingly, we did not notice any double infections when single lesions were analysed, in contrast to some previous findings. ${ }^{31}{ }^{32}$ However, seven patients with double infections were found when biopsies from different lesions were taken into account, that is, one from an exophytic wart and another from an adjacent flat lesion.

We can conclude that peniscopy is a clinically useful and mandatory diagnostic tool to be included in the satisfactory clinical evaluation of any patient with suspected HPV infection. This is so notwithstanding that conclusive criteria for peniscopically flat lesions cannot be given. Sharp demarcation of the lesions is highly suspicious for HPV infection, whereas a punctuated capillary pattern frequently suggests a PIN. Histological evaluation is needed to confirm the diagnosis. However, caution should be exercised while interpreting the nonclassic histological criteria (without typical koilocytosis) as an HPV lesion, viral typing being required to confirm the diagnosis in doubtful cases. The role of the clinician is to be emphasised; he or she must be able to conclude the case on the basis of the results from different diagnostic methods. According to our experience, a restrictive attitude to the therapy of male genital lesions seems feasible, especially when there are only subclinical (peniscopically detected) lesions without symptoms. This is particularly recommended if the lesions are not typically HPV-related or no high risk types have been found. It should be remembered that many therapies are quite ablative and there seems not to be very effective methods for treating flat lesions, though laser therapy seems to be most suitable. Many lesions also seem to disappear while just waiting (data not shown) and the malignant transformation is actually very rare. However, exophytic warts are better treated (for at least cosmetic reasons), as also men with symptoms. By following peniscopically symptomless patients to see if their lesions progress or regress we could also learn more about the biological behaviour of the male genital infection.

This study has been supported in part by a research gran from the Finnish Cancer Society, a research contract (\#104 1051) and a research grant from the Medical Research Council of the Academy of Finland, and by a joint research grant from the Fabrique de Tabac Reunies S.A. and Britis American Tobacco Company (BAT) Ltd. The HPV DNA probes were kindly provided by Prof. Harald zur Hausen, DKFZ, Heidelberg, PrZ, Heidelberg, and Prof. Gerard Orth, Institute Pasteur, (The skillfu technical assistance of Ms. Helena Kemiläinen, Ms. Kaarin Hoffren, and Ms. Paula Lipponen is also gratefully acknowledged.

Cocks PS, Peel KR, Cartwright RA, Adib R. Carcinoma of penis and cervix. Lancet 1980;ii:855-6.

2 Hellberg D, Nilsson S. Genital cancer among wives of men with penile cancer. A study between 1958 and 1982. Br f Obstet Gynecol 1989;96:321-5.

3 Syrjänen, KJ. Papillomaviruses and Cancer. In: Syrjänen $\mathrm{K}$, Gissmann L, Koss LG, eds. Papillomaviruses and Human Disease. Heidelberg, Springer Verlag, 1987: 468-503.

4 Barrasso R, de Brux J, Croissant O, Orth G. High prevalence of papillomavirus-associated penile intraepithelial neoplasia in sexual partners of women with cervical neoplasia in sexual partners of women with cervical
intraepithelial neoplasia. $N$ Engl $f$ Med 1987;317: 916-23.

5 Krebs H-B. Genital HPV infections in men. Clinic Obstet Gynaecol 1989;32:180-90.

6 Levine RU, Crum CP, Herman E, Silvers D, Ferenczy A, Richart RM. Cervical papillomavirus infection and intraepithelial neoplasia: a study of male sexual partners. Obstet Gynecol 1984;154:16-20.

7 Sedlacek TV, Cunnane M, Carpiniello V. Colposcopy in the diagnosis of penile condyloma. Am $\mathcal{F}$ Obstet Gynecol $1986 ; 154: 494-6$

8 Syriänen KJ. Association of HPV with penile cancer. In: Mindel A. ed. Genital Warts- Human papillomavirus Infection. Kent. Edward Arnold, In press. 1993.

9 Barrasso R, Jablonska S. Clinical, colposcopic and histologic spectrum of male human papillomavirus-associlogic spectrum of male human papilomavir.

10 Hippelainen M, Yliskoski M, Saarikoski S, Syrjänen S, Syrjänen $\mathrm{K}$. Genital human papillomavirus lesions of the male sexual partners: the diagnostic accuracy of peniscopy. Genitourin Med 1991;67:291-6.

11 Costa S, Syrjänen S, Vendra C, et al. Detection of human papillomavirus infections in the male sexual partners of women attending an STD clinic in Bologna. Int $f$ STD AIDS 1992;3:338-46.

12 Wickström A, Hedblad M-A, Johansson B, et al. The acetic acid test in evaluation of subclinical genital papillomavirus infection: a comparative study on penoscopy, histopathology, virology and scanning electron microscopy findings. Genitourin Med 1992;68:90-9.

13 Tabrizi SN, Tan J, Quinn M, Borg AJ, Garland SM. Detection of genital human papillomavirus (HPV) DNA by PCR and other conventional hybridisation techniques in male partners of women with abnormal Papanicolaou smears. Genitourin Med 1992;68:370-3.

14 Syrjänen S, Syrjänen, K. Human papillomavirus (HPV) infections of the genital tract. Clinical significance and diagnosis by PCR. In Becker Y, Darai G, eds. Frontiers in Virology: Diagnosis of Human Viruses by Polymerase Chain Reaction Technology. Heidelberg: Springer-Verlag, 1992:185-207.

15 Schultz R, Miller JW, MacDonald GR, et al. Clinical and molecular evaluation of acetowhite genital lesions in men. $₹$ Urol $1990 ; 143.9200-3$.

16 Nuovo GJ, Becker J, Margiotta M, MacConnell $P$, Comite S, Hochman $\mathbf{H}$. Histological distribution of polymerase chain reaction-amplified human papillopolymerase chain reaction-amplified human papillo-
mavirus 6 and 11 lesions. Am $₹$ Surg Pathol 1992;16: mavirus

17 von Krogh G, Syrjänen S, Syrjänen KJas. Advantage of human papillomavirus typing in the clinical evaluation of genital warts. Experience with the in situ deoxyribonucleic acid hybridization technique applied in paraf fin sections. F Am Acad Dermatol 1988;18:495-503.

18 Syrjänen KJ. Genital Human papillomavirus (HPV) infections and their associations with squamous cell cancer: Reapprisal of the morphologic, epidemiologic and DNA data. In: Fenoglio-Preiser CM, Wolff M, Rilke F, eds. Progress in Surgical Pathology. New York, Field \& Wood. 1992;12:217-40.

19 Sonnex C, Scholefield JH, Kocjan G, Whatrup C, Mindel A, Northover JMA, Anal human papillomavirus infection: a comparative study of cytology, colposcopy and DNA hybridisation methods of detection Med 1991;67:21-5.

20 Syrjänen S, Partanen P, Syrjänen, K. Comparison of the in situ DNA hybridization protocols using S-labeled probes and biotin-labeled probes in detection of HPV DNA sequences. Cancer Cells 1987;5:329-36. 
21 Nuovo GJ, Hochman HA, Eliezri YD, Lastarria D, Comite SL, Silvers DN. Detection of human papillomavirus DNA in penile lesions histologically negative for condylomata: analysis by in situ hybridization and the polymerase chain reaction. Am $\mathcal{f}$ Surg Pathol 1990; 14:829-36.

22 Roman A, Fife $\mathrm{KH}$. Human papillomaviruses: are we ready to type? Clin Microbiol Rev 1989;2:166-90.

23 Schneider V. Microscopic diagnosis of HPV infection. Clinic Obstet Gynecol 1989;32:148-56.

24 Syriänen KJ. Histopathology, cytology, immunohistochemistry and HPV typing techniques. In: von Krogh
chento Histopathology, cytology, immunohistochemistry and HPV typing techniques. In: von Krogh Survey for the Clinician, Karlstad, Sweden: Conpharm AB, 1989:33-67.

25 Spitzer M, Chernys AE, Hirschfield L, et al. Assessment of criteria used in the histologic diagnosis of human papillomavirus-related disease of the female lower genital tract. Gynecol Oncol 1990;38:105-9.

26 Richart RM, Nuovo GJ. Human papillomavirus DNA in situ hybridization may be used for the quality control of genital tract biopsies. Obstet Gynecol 1990;75:223-6.

27 Syrjänen S, Syrjänen K. An improved in situ DNA hyrjanen $S$, Syrjanen $K$. An improved in situ DNA
hybridization protocol for detection of human papillo- mavirus (HPV) DNA sequences in paraffin-embedded biopsies. F Virol Meth 1986;14:293-304.

28 Syrjänen S, Partanen P, Mäntyjävi R, Syrjänen, K. Sensitivity of in situ hybridization techniques using biotin- and S-labeled Human papillomavirus (HPV) DNA probes. F Virol Methods 1988;19:225-38.

29 Griffiths M, Penna LK, Tovey ST. Aceto-white change of the glans penis associated with balanitis not human
papillomavirus infection. Int $\mathcal{f} S T D$ AIDS 1991;2: papilloma

30 Weaver MG, Abdul-Karim FW, Dale G, Sorensen K, Huang YT. Detection and localization of human papillomavirus in penile condylomas and squamous cell carcinomas using in situ hybridization with biotinylated DNA viral probes. Modern Pathology 1989;2:94-100.

31 Del Mistro A, Braunstein JD, Halwer M, Koss LG. Identification of human papillomavirus types in male urethral condylomata acuminata by in situ hybridization. Hum Pathol 1987:18:936-40.

32 Nuovo GJ, Darfler MM, Impraim CC, Bromley SE. Occurrence of multiple types of human papillomavirus in genital tract lesions, analysis by in situ hybridization and the epolymerase chain reaction. Am $\mathcal{f}$ Pathol and the epolym
$1991 ; 58: 518-23$ 